\title{
The projection of rice production in Java Island to support Indonesia as the world food granary
}

\author{
Erni Susanti ${ }^{1}$, Elsa Rakhmi Dewi ${ }^{1 *}$,Elza Surmaini $^{1}$, Ardhasena Sopaheluwakan ${ }^{3}$, Aji \\ Linarko $^{3}$, and Muhammad Ridho Syahputra ${ }^{2}$ \\ ${ }^{1}$ Indonesian Agro-climate and Hydrology Research Institute \\ ${ }^{2}$ Bandung Institute of Technology \\ ${ }^{3}$ Meteorological, Climatological, and Geophysical Agency
}

\begin{abstract}
The use of climate projections such as Cordex-SEA with crop simulation models can determine the projections of rice productivity in the future especially to meet the Indonesian vision as world food granary by 2045. This study aimed to 1) evaluate the projection of rice productivity and 2) compile a map of projected changes at the district level in Java Island in 2021-2035 and 2036-2050 for the RCP4.5 and RCP8.5 scenarios. The Agricultural Production System Simulator (APSIM) results based on the CSIROMK3.6 climate projection model for both scenarios in 20212035 showed that the impact of high productivity was high during the rainy season compared to the dry season. Districts with the increase of productivity indicate that these areas can be maintained or developed for rice crop. For the RCP4.5 scenario (rainy season) in the irrigated area, 41 districts out of 191 districts in Java Island had the class of up-high productivity changes. For the period of 2036 to 2050, there were fewer districts that had up-high productivity changes. The APSIM simulation results using HadGEM2 climate projections indicated more districts had decreased productivity in both year periods for both scenarios.
\end{abstract}

\section{Introduction}

Agriculture is one of the economic generation sectors as well as a pillar of support for food security and national resilience. The impacts of climate change on the agricultural sector are multidimensional, especially for agricultural production systems such as the availability of water, planting time, productivity, degradation of land resources, water and infrastructure. These impacts coupled with a decrease in the quality, fertility and capacity of land, leads a decrease in food production. This condition is further exacerbated by the increasingly limited availability of water and its decreasing quality, which causes the decline in agricultural production.

The data indicates that the impacts of climate change are already being felt in Indonesian territory. In the last 50 years there has been a faster temperature increase of $0.16^{\circ} \mathrm{C}$ per decade. The increase in sea level, especially in the central and eastern parts of Indonesia, is 0.2-0.6 cm per year. During the period 1999-2010 there has been an increase

\footnotetext{
* Corresponding author: elsarakhmi@gmail.com
} 
in the intensity of rain in most parts of Java, Kalimantan and Papua. Whereas, in parts of the coastal areas of Sumatra, most of Sulawesi and Maluku, the trend of rainfall is decreasing. Of the various impacts, extreme climate events have the most impact at this time [1]. Boer [2] reported that the loss of rice production due to drought and floods in ENSO reached 2 million tonnes. In weak and moderate El Niño conditions, the loss of rice production is higher, reaching 1.3 million tonnes in the dry season alone [3].

Another challenge that must be met is the increase of population. Indonesia's population is projected to reach 305 million people by the year 2030 (www.bps.go.id/linkTabelStatis/view/id/1274), which will increase the need for food supply. The World Food Program [4] estimates that the world needs 50\% more food production by the year 2030 in order to meet the demands of an increasing population. At the same time, the impact of climate change is projected to see a $1-7 \%$ reduction in world food production by the year 2060. If the impacts of climate change are not anticipated, it is estimated that around $20 \%$ of the world's population is at risk of starvation. Boer [2] stated that the decline in rice production in Java in 2025 due to temperature increases and land conversion will reach 6 million tons and in 2050 it will reach more than 12 million tons, assuming a paddy field conversion rate of $0.77 \%$ per year.

Amid the worries and uneasiness of the world community over food and the growing threat and risk of climate change, Indonesia remains confident that it will soon achieve food self-sufficiency and sovereignty. Even Indonesia has an ambition to become one of the world food granaries in the future. This ambition, of course, takes into account various strategic factors and potential resources that can be utilized optimally [5].

To support Indonesia as the world food granary by 2045, the spatial projection component of rice production, especially in food production centres, is one of the keys to get a projection picture of rice production in the future. Although climate projections leave a lot of uncertainty, analytical efforts to get a picture of the impacts of climate change need to be done. Furthermore, long-term adaptation strategies need to be prepared from now on, such as planning for infrastructure that needs to be built, developing new areas that are more resilient to the impacts of climate change, and developing varieties that are more tolerant of extreme conditions [6].

As one of the obligations of countries to prepare for climate change adaptation, the availability of high-resolution climate change scenarios is the main requirement for conducting various impact-based studies. Indonesia through the Meteorological, Climatological, and Geophysical Agency/Badan Meteorologi, Klimatologi dan Geofisika (BMKG) with countries in the Southeast Asia region through the Southeast Asia Regional Climate Downscaling (SEACLID) collaboration has carried out the process of downscaling the output of Coupled Model Intercomaprison Project 5 (CMIP5) for the Southeast Asia region. The results of the downscaling in the form of high-resolution climate change scenario data $(25 \times 25 \mathrm{~km})$ for the Southeast Asia region can be used for a study of the impact of climate change in various sectors including the agricultural sector. The climate projection impact assessment can then be integrated with a crop simulation model. One of the most widely used crop simulation models for climate change impact studies is the APSIM (Agricultural Production System Simulator) which is a multipurpose software system which can simulate agricultural production systems in response to the environment [7], especially in dealing with climate risks [8]. In addition, APSIM has the capacity to identify not only future climate impacts, but also adaptation in response to changing ricebased cropping systems.

The integration of climate projections and crop simulation model can provide information on rice production anomalies due to climate change. This can be projected until the period of 2045, which is the target time for Indonesia to become the world food granary. Based on the projection results, it can be seen that areas that will experience a 
decline in production due to rising temperatures and areas that have the potential to become a new rice production centres. Further, the information is very important in regional development planning and technology to support the achievement of rice production targets. This study therefore aimed to evaluate the projection of rice productivity and compile a map of projected changes at the district level in Java Island in 2021-2035 and 2036-2050 using the Representative Concentration Pathway (RCP) 4.5 and 8.5 scenarios.

\section{Materials and methods}

\subsection{Scope of activities}

An integrated system of climate projections and crop simulations was built as the basis of this research. Climate projections are the result of downscaling from global to regional models, the climate projection output then was used directly for crop simulations. The daily climate projection database (rainfall, maximum temperature, minimum temperature and solar radiation) was built for each grid as the data used was considerably a lot. Soil databases were collected from the results of land surveys at the Indonesian Centre for Agricultural Land Resources Research and Development (ICALRRD). Crop data (such as variety and phenology) and farmers' cultivation practices for rice were collected through focus group discussion (FGD) with the extension workers and agricultural department staff. The next stage was parameterization of the APSIM model so that the simulation results could approach the observation results based on research studies.

Crop simulations were run for the baseline (1991-2005) and projection (2021-2035 and 2036-2050) periods for the RCP4.5 and RCP8.5 scenarios during rainy and dry season with recommended applications on irrigated rice fields. The difference between the baseline and projection productivity was the change in rice productivity to existing productivity. Based on the projected map of changes in rice productivity for the periods 2021-2035 and 20362050, recommendations for technology, regional development and infrastructure can be prepared to support Indonesia's achievement to become a world food granary by 2045 .

\subsection{Research data}

\subsubsection{Climate data}

Daily climate data such as rainfall, minimum temperature, maximum temperature and radiation for all districts in 5 provinces: Banten, West Java, Central Java, DI Yogyakarta and East Java. The data sources used were the Cordex-SEA baseline data (1991-2005) and projections (2021-2035 and 2036-2050) from 2 Global Climate Models (GCM) obtained from BMKG and daily climate data observations from the BMKG climate/rainfall station, office of public works-irrigation, as well as the Ministry of Agriculture;

Climate models are developing rapidly so that they are able to model the climate system more comprehensively; coupled with oceans, incorporate the carbon cycle on land, dynamically incorporating atmospheric chemistry, ice sheets and vegetation $[9,10,11]$. The new scenario is known as Representative Concentration Pathways (RCP) is used as the basis for making climate change projections adopted in the fifth report (Fifth Assessment Report) of the IPCC replacing the role of the SRES scenario in the fourth report (Fourth Assessment Report). Cordex-SEA decided to use only 2 (two) RCP scenarios out of 4 (four) available scenarios, taking into account that two scenarios (RCP4.5 and 8.5) reflect conditions as realistic lower bounds and worst case scenarios as conditions of the upper limit. The GCM projection models used in this study are CSIROMK3.6 and HadGEM2. 


\subsubsection{Soil data}

Soil data cover drainage class, availability of ground water for crop, bulk density, percentage of sand, dust and clay, field capacity, permanent wilting point, organic Carbon, and $\mathrm{pH}$ for 2 levels of soil depth; $0-30 \mathrm{~cm}$ and 30-100 cm depth collected for 267 grids in Java Island based on the grid boundaries of the Cordex projection masking results as shown in Figure 1. Soil data were collected from the ICALRRD, Indonesian Soil Research Institute, and libraries. Grids with no soil data from the ICALRRD database were then obtained through the Harmonized World Soil Database (HWSD). The HWSD allows soil composition to be displayed or queried in terms of user-selected soil parameters.

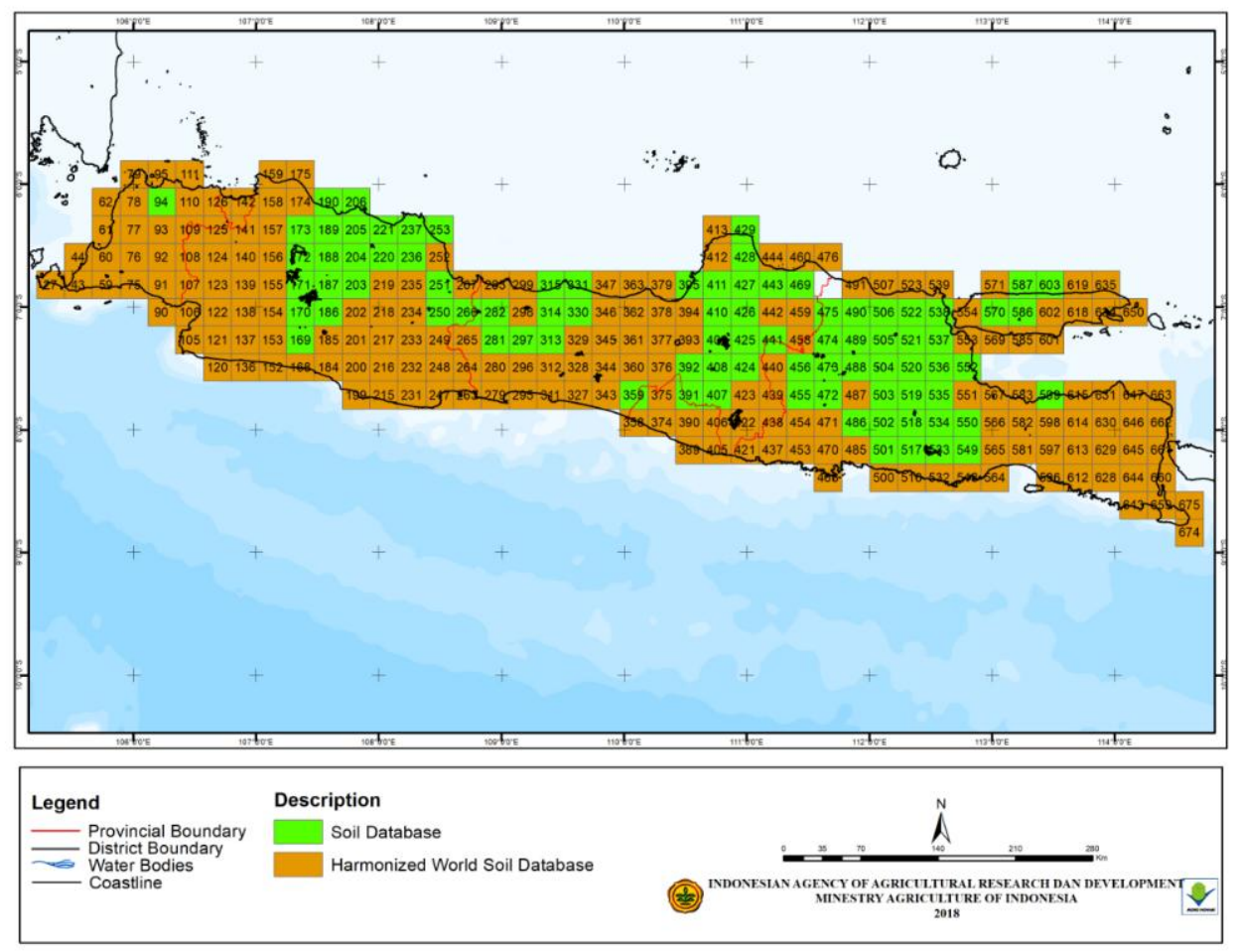

Fig. 1. Soil data sources per grid for crop simulation 
Table 1. Soil physics and chemistry data from HWSD used for APSIM simulation

\begin{tabular}{|c|c|c|c|c|c|}
\hline Soil map & 3643 & 3749 & 3784 & 3856 & 4455 \\
\hline Kode Tanah & 1 & 2 & 3 & 4 & 5 \\
\hline Soil Unit Name (FAO74) & Dystric Cambisols & Calcaric Fluvisols & Chromic Luvisols & Humic Andosols & Gleyic Acrisols \\
\hline Drainage class (0-0.5\% slope) & Moderately Well & Very Poor & Moderately Well & Moderately Well & Poor \\
\hline AWC $(\mathrm{mm})$ & 150 & 150 & 150 & 150 & 150 \\
\hline \multicolumn{6}{|l|}{$0-30 \mathrm{~cm}$} \\
\hline Topsoil Sand Fraction (\%) & 41 & 12 & 26 & 34 & 34 \\
\hline Topsoil USDA Texture Classification & loam & clay (light) & clay (light) & loam & loam \\
\hline Topsoil Bulk Density (kg/dm3) & 1.3 & 1.26 & 1.35 & 0.71 & 1.39 \\
\hline Topsoil Organic Carbon (\% weight) & 1.45 & 2.22 & 1.22 & 7.37 & 0.83 \\
\hline Topsoil pH (H2O) & 5.1 & 4.8 & 6.3 & 5.4 & 4.9 \\
\hline Subsoil USDA Texture Classification & loam & clay (light) & clay (light) & loam & clay loam \\
\hline Subsoil Bulk Density (kg/dm3) & 1.37 & 1.44 & 1.4 & 0.71 & 1.48 \\
\hline Subsoil Organic Carbon (\% weight) & 0.5 & 0.65 & 0.58 & 3.33 & 0.3 \\
\hline Subsoil pH (H2O) & 5.2 & 4.6 & 6.4 & 5.9 & 4.7 \\
\hline
\end{tabular}

\subsubsection{Rice crop data}

Data on rice crops covering varieties, crop age, crop phenology phase, rice productivity, and; Data for parameterizations were collected from various germplasm research results at the Rice Research Institute, Sukamandi. The required data are planting date, harvest date, $50 \%$ flowering age (days) and grain yield $(\mathrm{kg} / \mathrm{ha})$, type of irrigation, time of application and dose of fertilizer.

\subsubsection{Crop management data}

Crop cultivation technology implemented by farmers such as planting time, type of rice field (irrigation/rainfed), and fertilization were collected by interviewing farmers.

\subsection{Methods of analysis}

\subsubsection{APSIM model setup}

The APSIM model version 7.9 was configured with modules for rice, ground water (SOILWAT), nitrogen in soil (SOILN), crop residues (Surface OM), and crop management practices [7]. These modules were then connected to the APSIM central engine to simulate rice crop in a rice-based cropping system in Java Island.

\subsubsection{Parameterisation of the APSIM model}

Soil modules namely SOILWAT and SOILN were parameterized according to standard practice in APSIM. For the selected location, the parameters for the SOILWAT module include bulk density, field capacity, permanent wilting point, $\mathrm{pH}$ and soil texture. Parameters for the SOILN module include organic carbon (OC), $\mathrm{pH}$, Finert (inert $\mathrm{C}$ fraction) and Fbiome (microbial biomass fraction). Finert and Fbiome, different sets of organic matter based on specific default values, represent a portion of the total organic carbon in a given location $[12,13]$. 
For rice crop, rice varieties were parameterized using the dominant rice varieties from the literature review (Inpari13) according to the procedure described in APSIM. Phenological parameters include early growth phase, active tiller phase, panicle formation phase, and flowering phase. Furthermore, the parameter values of each phase of phenological development were adjusted until the value of the simulation phase matches the value of the observation phase.

\subsubsection{Analysis of crop simulation}

Crop simulation model was developed to identify and evaluate projection of rice productivity in Java island for the periods 2021-2035 and 2036-2050 using the downscaling of the Cordex-SEA climate projection scenarios RCP4.5 and RCP8.5. The cultivation recommendation technology applied to the rice planting system was described as follows:

1. Planting time: based on integrated cropping calendar information system [14] recommendation ( $1^{\text {st }}$ of November for rainy season, and $1^{\text {st }}$ of April for dry season)

2. Water treatment: Irrigated rice; water supply was applied in accordance with the recommended technology

3. Fertilization: type, dosage, and timing of fertilization based on recommended technology i.e. three times at 7 days after planting (100 $\mathrm{kg} \mathrm{ha}^{-1}$ of Urea), 21 days after planting ( $75 \mathrm{~kg} \mathrm{ha}^{-1}$ of Urea) and 35 days after planting ( $75 \mathrm{~kg} \mathrm{ha}^{-1}$ of Urea)

4. Crop residue: the amount and time to return the remaining plant parts into the soil based on recommended technology

The system was then compiled using APSIM's Manager and simulated, starting $1^{\text {st }}$ of January 2020 until $31^{\text {st }}$ of December 2045 for each RCP scenarios. Soil water, soil mineral $\mathrm{N}$ and soil organic matter were reset to initial conditions.

\subsubsection{Productivity projection change analysis}

To get the value of changes in rice productivity for the periods of 2021-2035 and 20362050 , the simulated rice productivity for the projection periods of 2021-2035 and 20362050 was reduced by the simulated rice productivity for the baseline period (1991-2005). Projections were carried out in 2 climate scenarios, namely RCP4.5 and RCP8.5.

\subsubsection{Making of mainstay rice production centers map to support Indonesia as world food granary}

Map of the mainstay rice production center development area was shown by the region/district. The value of change in rice productivity per district was obtained by averaging the values per grid for all grids in the district/city. The value was then classified into 3 criteria of changes in rice productivity; high rise, medium rise and low rise so it was when rice productivity is low. The criteria of changes were; low $=0-10 \%$, moderate $=10-20 \%$ and high $>20 \%$. Recommendations for the development of mainstay rice production centers were selected areas which have positive productivity changes and were higher than 20 percent. 


\section{Results and discussion}

\subsection{Plant phenology data}

Rice crop data include varieties, plant age, plant phenology phase, rice production/productivity. The variety used in this research was determined by the availability of data for parameterization. Data for parameterizations were collected from various germplasm research results at the Rice Research Institute, Sukamandi. The required data are planting date, harvest date, 50\% flowering age (days) and grain yield ( $\mathrm{kg} / \mathrm{ha}$ ), type of irrigation, time of application and dose of fertilizer. The compiled data include 79 results of research conducted in the period 2010 - 2014. The research locations were in West Java, Central Java and East Java.

\subsection{Parameterization}

The APSIM model was parameterized using data from field experiments conducted by Rice Research Institute in 2012 and 2013, in Rancakasuma District, Ciparay Regency, West Java. The rice variety used was Inpari13 and daily climate data for the period 2012-2013 in Ciparay Regency was used as input for climate data.

The Inpari13 rice variety was calibrated by adjusting the rice plant phenological parameters on ORYZA2000. The parameters used were the results of the best fitting between simulated and observed data. The phenological parameters were set based on the time (record date) of the planting phase, formation and physiological maturity in field experiments. Parameter values were then adjusted until the phenological phase simulation matches the observed values. Planting dates used were 01 May 2012 and 13 May 2013 with irrigation of $10 \mathrm{~mm} /$ day. Fertilization was applied three times at 7 days after planting (80 $\mathrm{kg} \mathrm{ha}^{-1}$ of Urea), 30 days after planting and 50 days after planting (85 $\mathrm{kg} \mathrm{ha}^{-1}$ of Urea), respectively. The soil data used was soil data from the HWSD database and the defaults in the SoilWat and SoilN modules on APSIM.

Figure 2 shows the performance of the APSIM model in simulating rice productivity. The simulated values were compared to the observed values. The simulated value of rice productivity in 2012 ( 7.09 ton $\left.^{-1} \mathrm{a}^{-1}\right)$ showed a value that was the same as the observed one ( 7.11 ton $\left.\mathrm{ha}^{-1}\right)$, also the simulated value of rice productivity in $2013\left(6.42\right.$ ton $\mathrm{ha}^{-1}$ ) was comparable to the observed value (6.35 ton $\left.\mathrm{ha}^{-1}\right)$. The simulation results indicate that the APSIM model was able to estimate rice productivity smoothly based on the given water and fertilizer application.

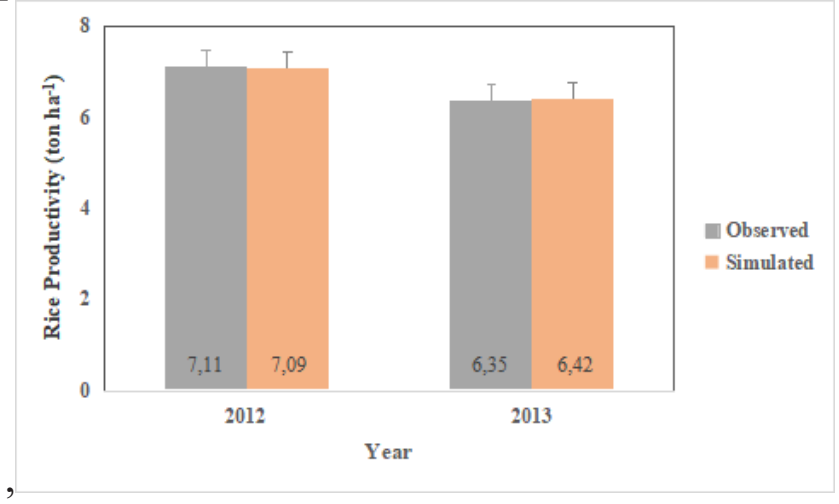

Fig. 2. Simulated and observed values of rice productivity (ton $\mathrm{ha}^{-1}$ ) based on field experiments in Rancamaya District, Ciparay Regency for the period of 2012 and 2013 


\subsection{Projected rice productivity in Java}

The crop simulation model is used to project rice production anomalies in Java. Two Cordex-SEA project models, CSIROMK3.6 and HadGEM2 were used as climate inputs in the APSIM model. The model was simulated for the 1991-2005 baseline period and two projection periods of 2021-2035 and 2036-2050. APSIM simulations were carried out on irrigated and rainfed rice fields in the rainy (MH) and dry season (MK) 2021-2035 and 2036-2050 for the RCP4.5 and RCP8.5 scenarios.

\subsubsection{CSIROMK3.6 model projection}

The projection of rice productivity in the rainy season (MH) for both periods 2021-2035 and 2036-2050 using CSIROMK3.6 model shows an increase in rice productivity for the RCP4.5 and RCP8.5 scenarios throughout Java. The highest increase will occur in West Java and Banten Provinces, which is greater than $20 \%$. The increase in productivity is due to an increase in rainfall up to $6 \mathrm{~mm}_{\text {day }^{-1}}$ and an increase in solar radiation of $0-5 \mathrm{MJ} \mathrm{m}^{-2}$ day $^{-1}$. Sufficient water conditions with abundant radiation allow the maximum photosynthesis process. The increase of irrigated rice productivity in Central Java, DIY and East Java provinces ranged from 10-20\% (Figure 7).

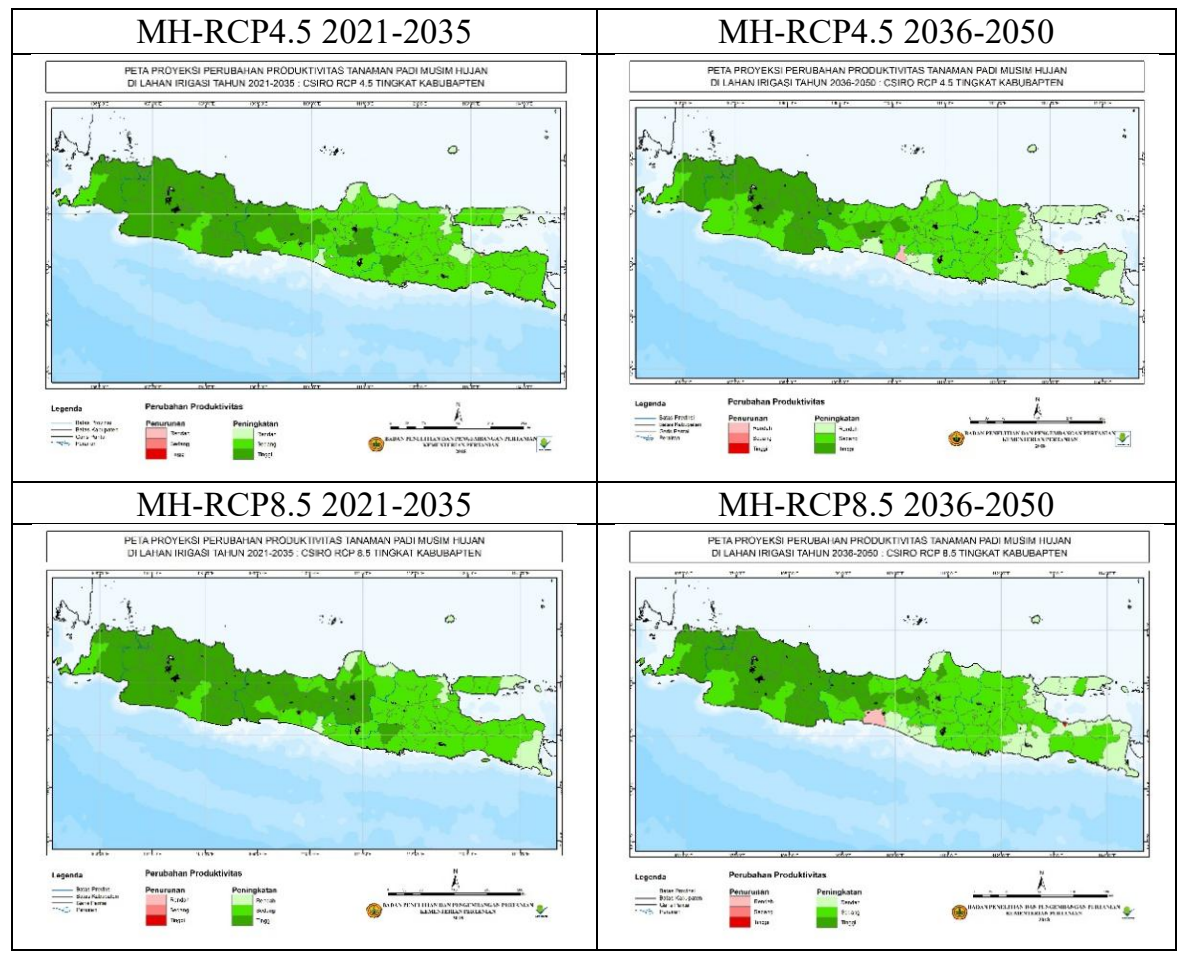

Fig. 7. Change projection of irrigated rice productivity in the rainy season (MH) 2021-2035 and 2036-2050 for the RCP4.5 and RCP8.5 scenarios using CSIROMK3.6 model

In the dry season (MK) 2021-2035 (Figure 8) the increase of rice productivity is projected to occur only in West Java and Banten, both for the RCP4.5 and RCP8.5 scenarios with a range of 10-20\%. On the other side, in 2036-2050, mainly part of West Java and Banten will experience a small increase up to $10 \%$. Rainfall changes between 2 seasons (MH and MK) are slightly small and accompanied by a decrease of radiation and 
an increase of temperature which may cause lower productivity. In irrigated rice fields, however, the availability of irrigation water is limited to the dry season (MK), with increasing temperature and radiation inducing low productivity. The consequence of the RCP8.5 scenario shows that a production decline of $>30 \%$ will occur in Central Java and parts of East Java Province

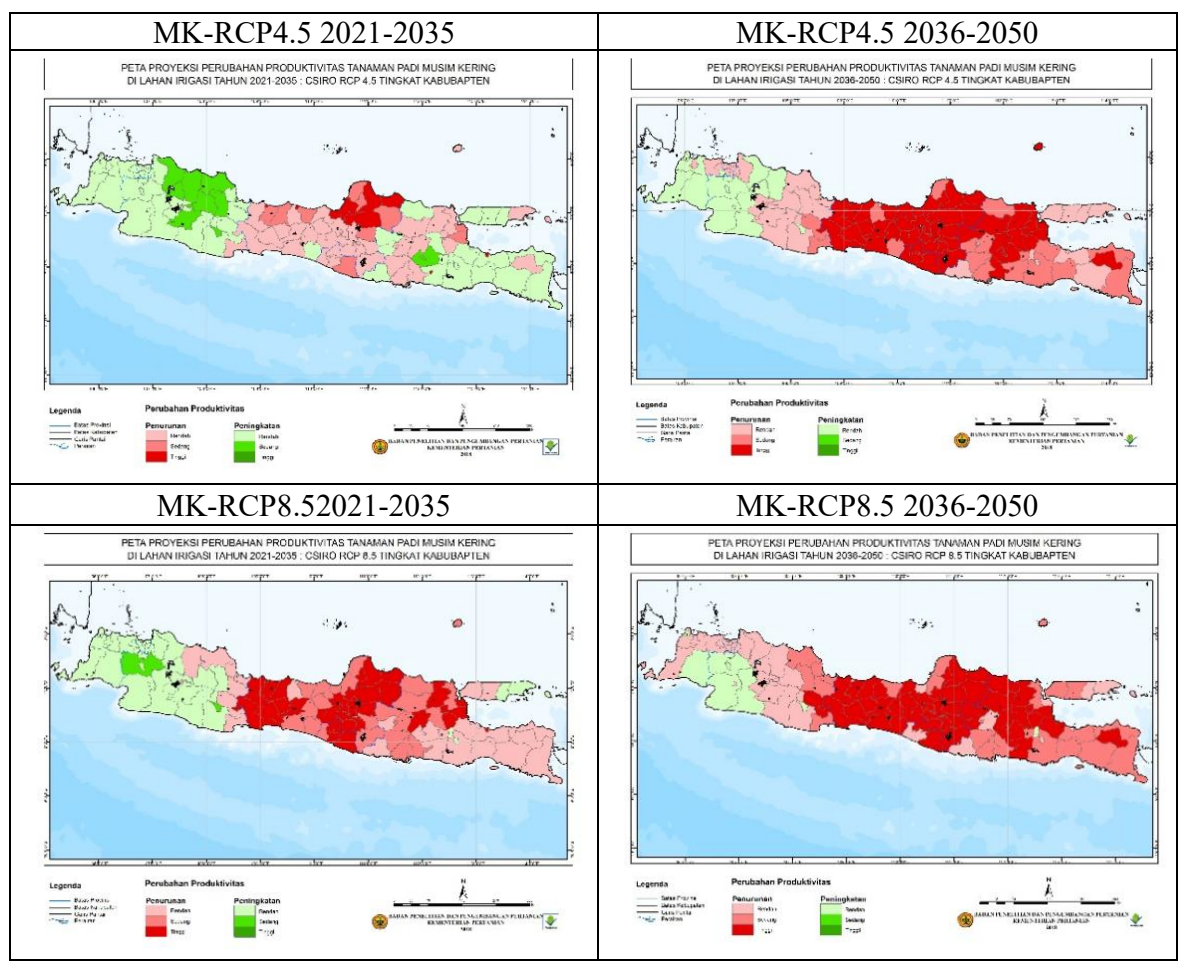

Fig. 8. Change projection of irrigated rice productivity in the dry season (MK) 2021-2035 and 20362050 for the RCP4.5 and RCP8.5 scenarios using CSIROMK3.6 model

\subsubsection{HadGEM2 model projection}

Change projection of irrigated rice productivity during rainy season using the HadGEM2 model is presented in Figure 9. APSIM simulation results show far productivity decline in the HadGEM2 model. 


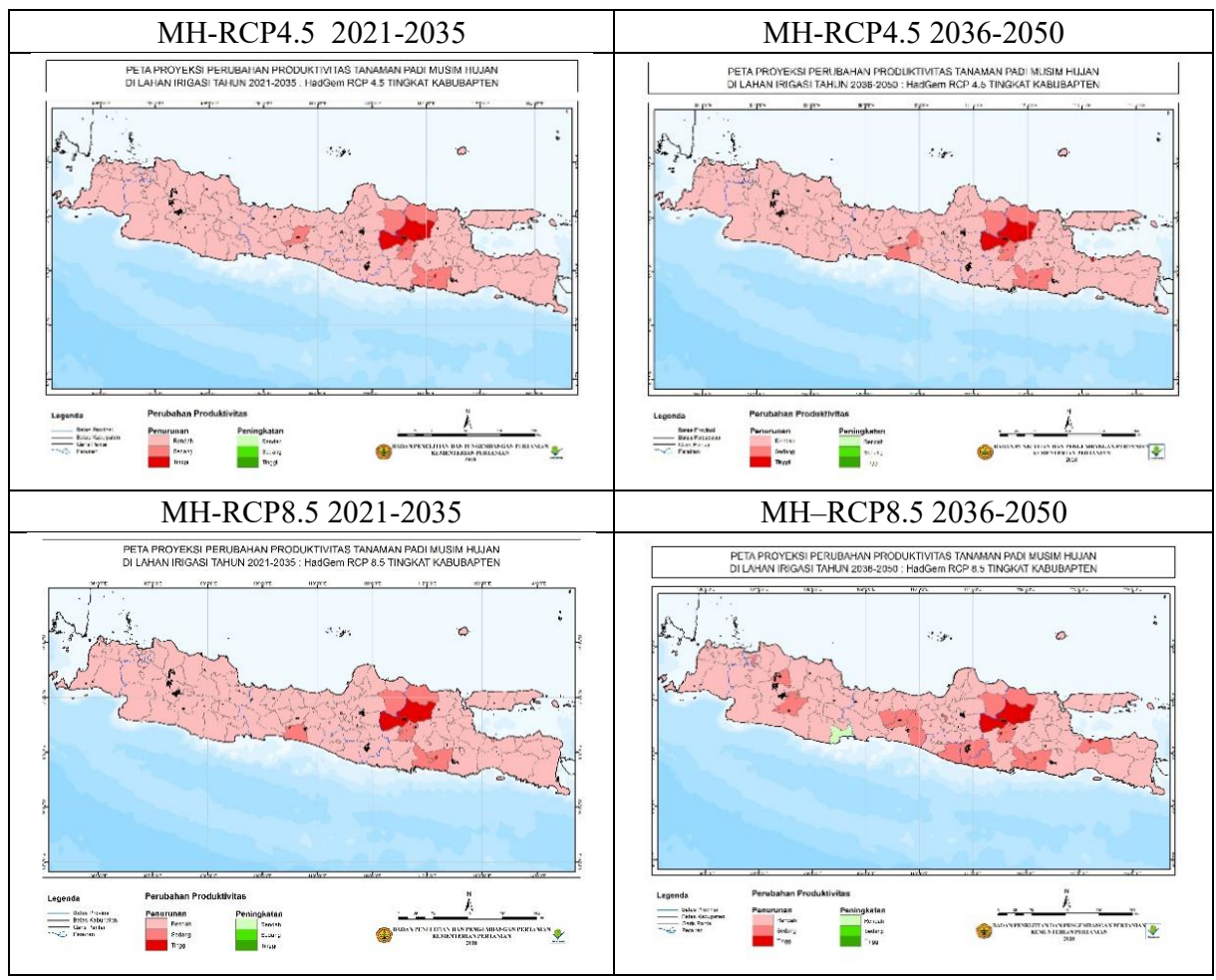

Fig. 9. Change projection of irrigated rice productivity in the rainy season (MH) 2021-2035 and 2036-2050 for the RCP4.5 and RCP8.5 scenarios using HadGEM2 model

The rainfall anomaly projection using the HadGEM2 model shows a pretty high value during rainy season $(\mathrm{MH})$ in irrigated rice fields. Even though the rainfall is projected to increase and irrigation is available, rice productivity may not go high as the radiation projection will decrease. The decrease in solar radiation causes the rate of photosynthesis for seed filling is not optimal. The projected decline in productivity in the period of 20212035 and 2036-2050 will occur throughout Java for both scenarios (RCP4.5 and RCP8.5). The decline in productivity is up to $20 \%$ for both scenarios, but the region is slightly high in the period of 2036-2050. The decline in productivity occurs because solar radiation is projected to fall for the entire Java region (Figure 9).

Different projections are generated during the dry season (MK) in irrigated rice fields (Figure 10). It is projected to increase productivity in Banten, West Java, and parts of East Java for the RCP4.5 scenario. The HadGEM2 model for both scenarios projects that rainfall will decrease 0-6 $\mathrm{mm} \mathrm{day}^{-1}$ in the dry season (MK) 2021-2035, whereas the rainfall decrease will reach $0-8 \mathrm{~mm}_{\text {day }^{-1}}$ in the dry season (MK) 2035-2050. Comparing to the CSIROMK3.6 model, the increase of $\mathrm{T}_{\min }$ is lower. 

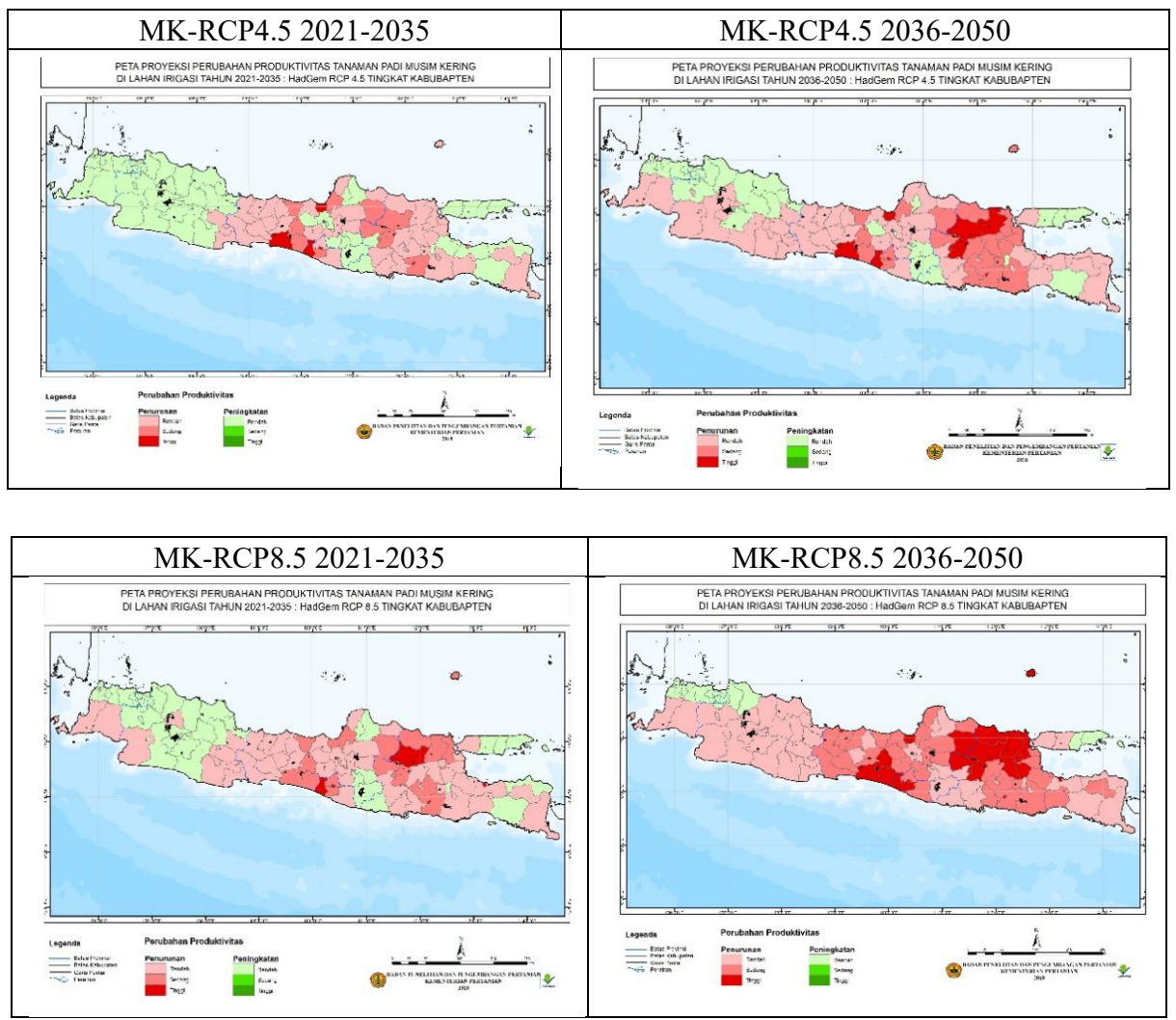

Fig. 10. Change projection of irrigated rice productivity in the dry season (MK) 2021-2035 and 20362050 for the RCP4.5 and RCP8.5 scenarios using HadGEM2 model

\subsection{Change projection of rice productivity at district level}

Change projection of rice productivity per district are obtained by averaging changes of rice productivity of each grid in a district. Figure 11 shows the spatial distribution of the productivity change classes from low $(0-10 \%)$, moderate $(10-20 \%)$ and high $(>20 \%)$. The results of crop simulation projected that in the next period (2021-2035 and 2036-2050) productivity would not always decrease, the CSIROMK3.6 model for the RCP4.5 and RCP8.5 scenario projected an increase of productivity, especially during the rainy season almost all over Java Island. 

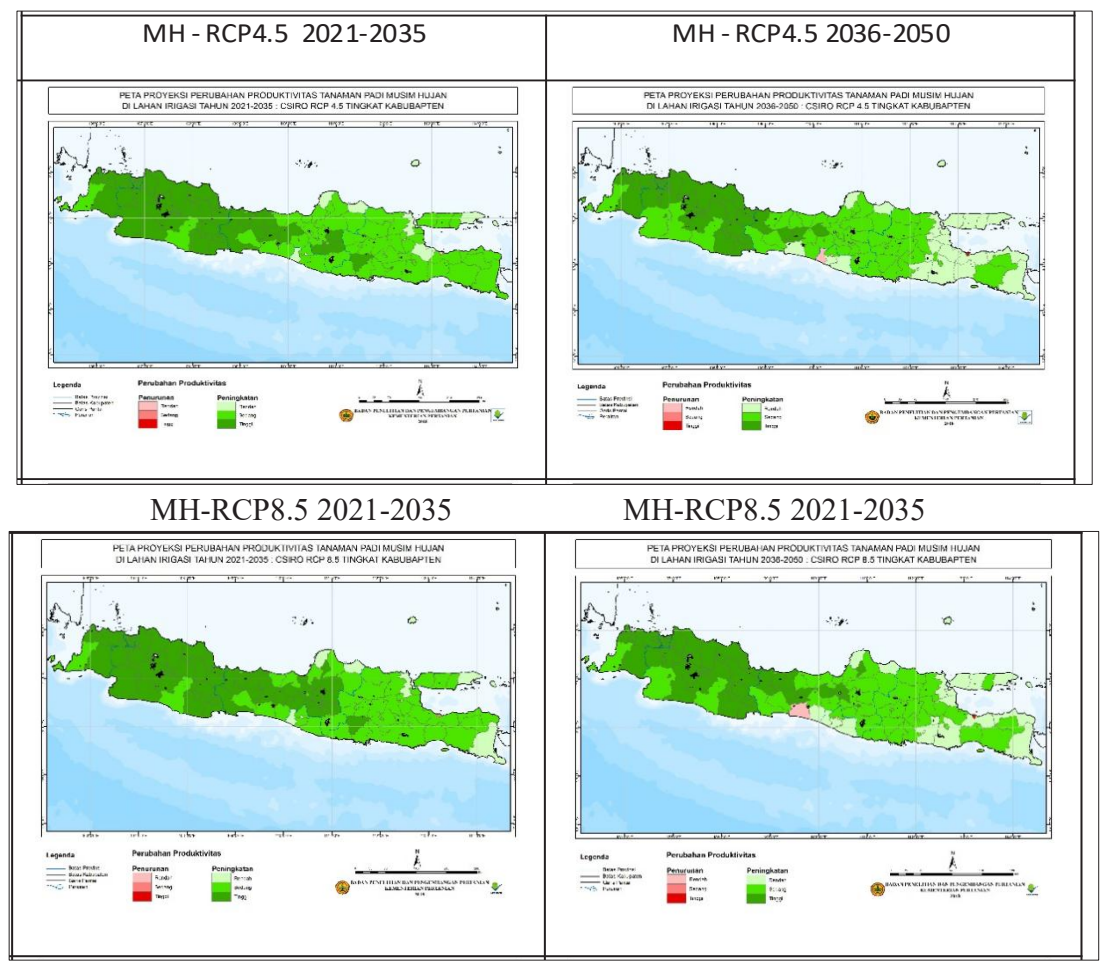

Fig. 11. Change of rice productivity at the district level in the rainy season (MH) using CSIROMK3.6 model

In the dry season (MK) the high increase class for the RCP4.5 scenario will be in Nganjuk, Kediri, Tulungagung, and Blitar districts, whereas for the RCP8.5 scenario will be in Kuningan district (Figure 12). 

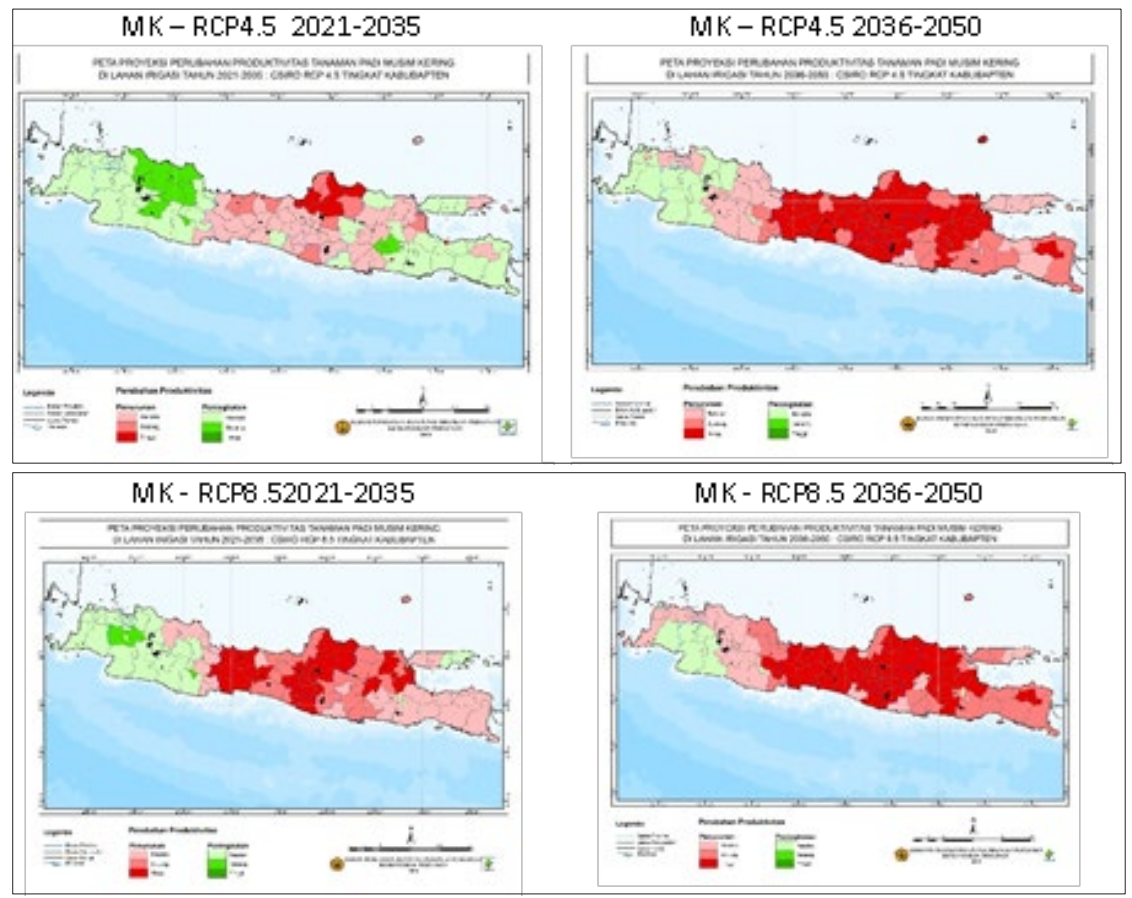

Fig. 12. Change of rice productivity at the district level in the dry season (MK) using CSIROMK3.6 model

The HadGEM2 model for both scenarios projects that in 2021-2035 and 2036-2050 there will be no increase in productivity, on the contrary, there will be a decrease in low, moderate and high productivity. In the rainy season $(\mathrm{MH})$, almost all productivity decrease in irrigated rice fields for the RCP4.5 and RCP8.5 scenario (Figure 13). 

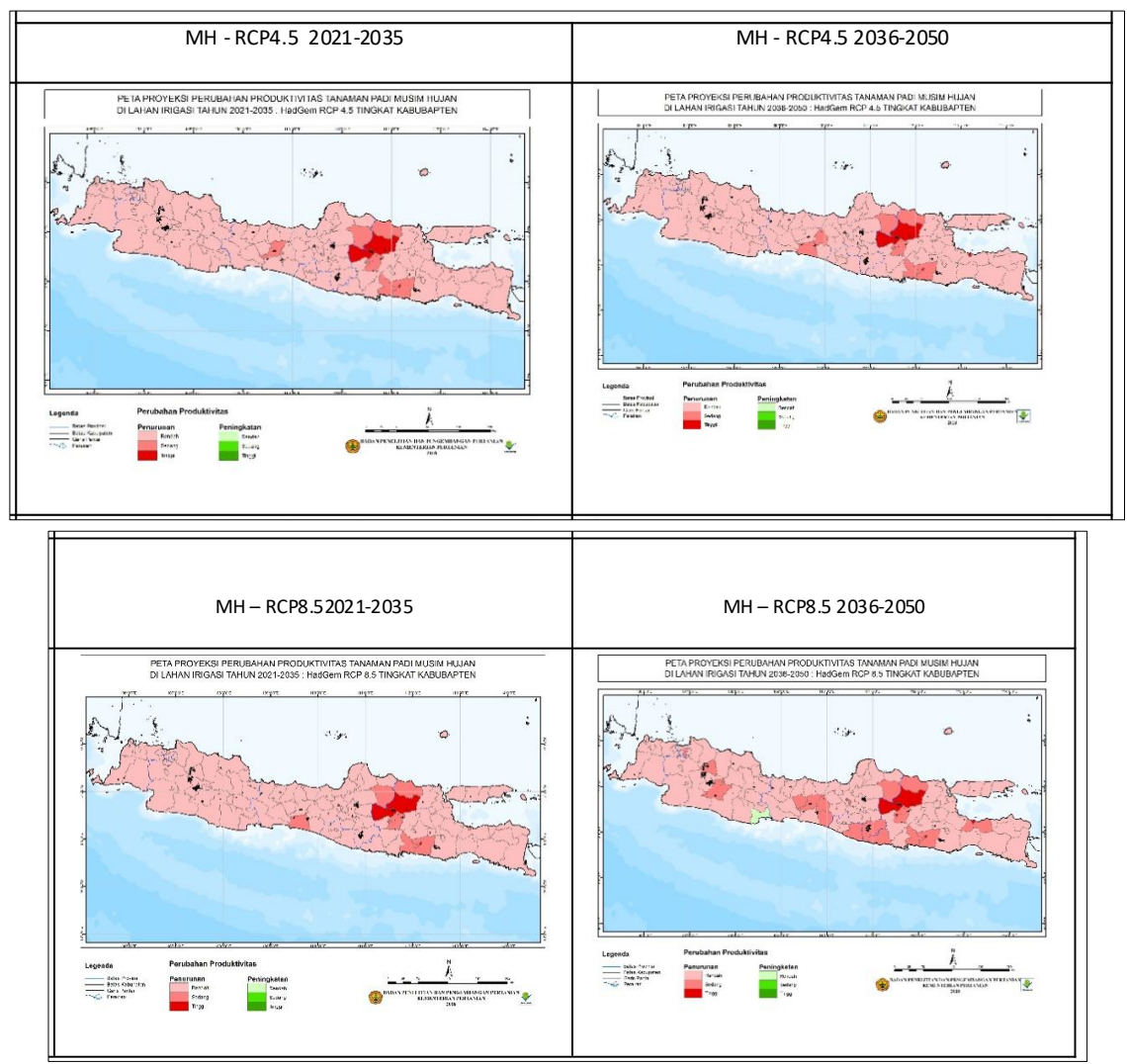

Fig. 13. Change of rice productivity at the district level in the rainy season (MH) using HadGEM2 model

In the dry season for the RCP4.5 scenario, most of the productivity increase slightly weak in irrigated rice fields in Banten and West Java Provinces and several districts in Central Java and East Java (Figure 14). 

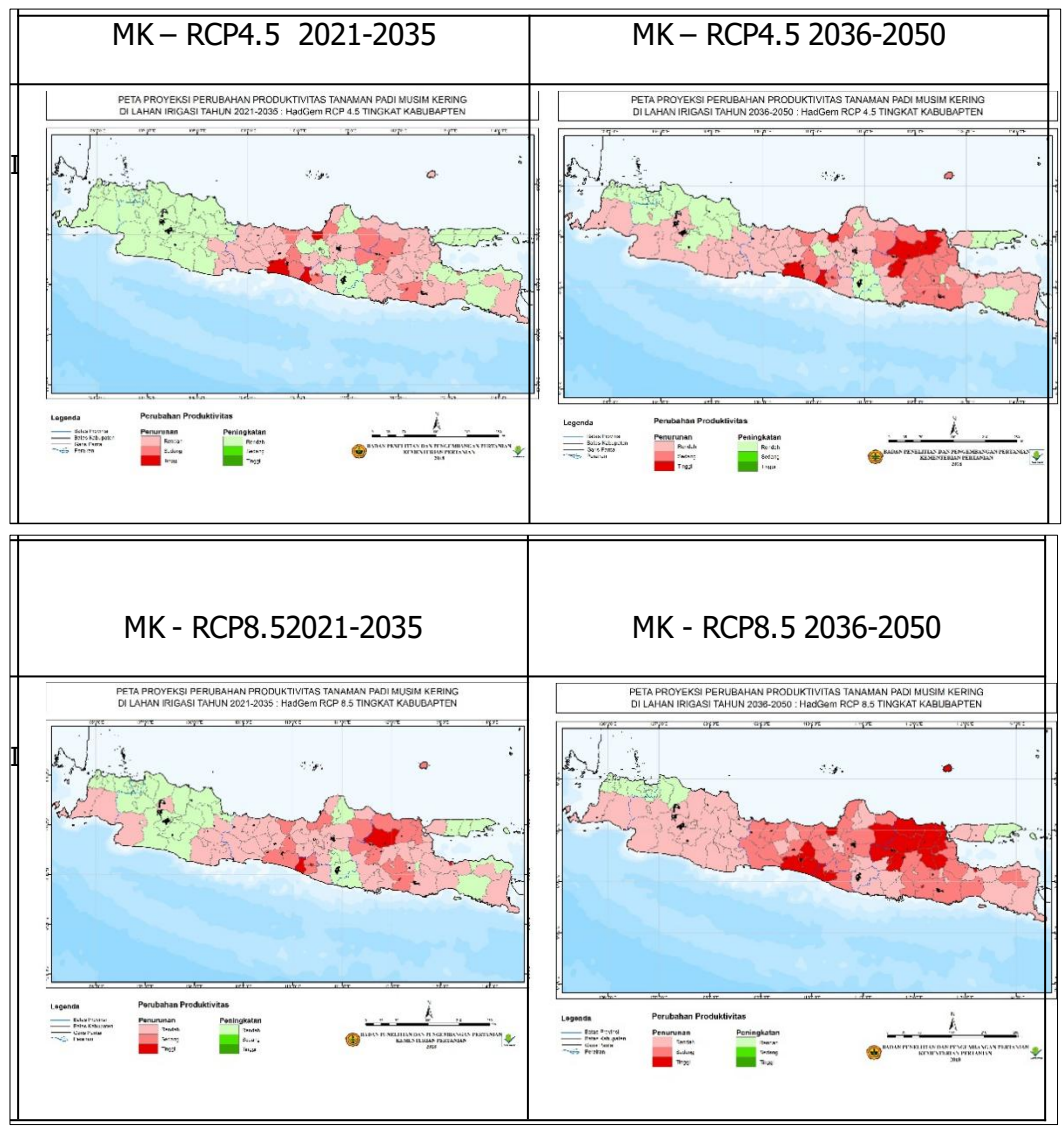

Fig. 14. Change of rice productivity at the district level in the dry season (MK) using HadGEM2 model

\section{Conclusions}

Referring to the CSIROMK3.6 projection, in the period of 2021-2035 the rainy season will have a high impact on increasing productivity compare to the dry season. There are 41 regencies/cities out of 191 districts/cities in Java Island.

The HadGEM2 model for both scenarios in the rainy season on irrigated fields shows a decrease of productivity changes. Change projection of rice productivity for the RCP8.5 scenario shows a more decrease of productivity than an increase of productivity. Adaptation efforts must be made for the areas that are projected to decrease productivity, so that rice productivity can be increase or remains constant.

From two global climate models, CSIROMK3.6 and HadGEM2, it is obtained that the rainfall climate projections, maximum temperatures and minimum temperatures are almost the same, but differ in radiation projections, resulting in different productivity projections. The CSIROMK3.6 model shows higher radiation baseline compare to HadGEM2 so that the APSIM plant simulation results in higher productivity than the HadGEM2 model. Changes in the radiation projection of the CSIROMK3.6 model from baseline (1991-2005) to the period 2021-2035, 2036-2050 increased by around 2-3 $\mathrm{MJ} \mathrm{m}^{-2}$, resulting in increased productivity changes. It is necessary to do it again by using climate projections from 
several other global climate models, so that the most common trends are known. To get the best productivity, it is also necessary to carry out simulations at several planting times.

\section{References}

1. R, Boer, Analisis risiko iklim untuk produksi pertanian, Presented on Lectures Training as Sumatra and Kalimantan in modeling, agriculture environment simulation, 1-13 Juli, Bogor, Indonesia (2002)

2. R, Boer, Ancaman perubahan iklim terhadap ketahanan pangan, Presented on National Workshop and FGD Adapatasi Perubahan Iklim, 9-10 November 2011, Bandung, Indonesia (2011)

3. E. Surmaini, T.W. Hadi, K. Subagyono, N.T. Puspito, Theor. Appl. Climatol. 121, 669$684(2015)$

4. Word Food Program, How climate change affect hunger, available at : http://www.wfp.org/climate-change (Acessed on $21^{\text {st }}$ Juli, 2016)

5. Ministry of Agriculture, Grand design pengembangan lumbung pangan beroreintasi eskpor di wilayah perbatasan (Kementerian Pertanian, Jakarta, 2017)

6. E. Surmaini, A. Faqih, J. Sumberd. Lahan. 10, 2, 115-128 (2016)

7. P.S. Carberry, S.G.K. Adiku, R.L. McCown, B.A. Keating, APSRU, 2-13 (1996)

8. B.A. Keating, P.S. Carberry, G.L. Hammer, M.E. Probert, M.J. Robertson, D. Holzworth, N.I. Huth, J.N.G. Hargreaves, H. Meinke, Z. Hochman, G. McLean, K. Verburg, V. Snow, J.P. Dimes, M. Silburn, E. Wang, S. Brown, K.L. Bristowc, S. Asseng, S. Chapman, R.L. McCown, D.M. Freebairn, C.J. Smith, Europ. J. Agronomy. 18, 267-288 (2003)

9. D.A. Randall, R.A. Wood, S. Bony, R. Colman, T. Fichefet, J. Fyfe, V. Kattsov, A. Pitman, J. Shukla, J. Srinivasan, R.J. Stouffer, A. Sumi, K.E. Taylor, Climate models and their evaluation, In Climate Change 2007: The physical science basis (Cambridge University Press, Cambridge, New York, USA, 2007)

10. P.M. Cox, R.A. Betts, C.D. Jones, S.A. Spall. I.J. Totterdell, Nature. 408, 184-187 (2000)

11. P. Friedlingstein, P. Cox, R. Betts, L. Bopp, W.V. Bloh, V. Brovkin, P. Cadule, S. Doney, M. Eby, I. Fung, G. Bala, J. John, C. Jones, F. Joos, T. Kato, M. Kawamiya, W. Knorr, K. Lindsay, H.D. Matthews, T. Raddatz, P. Rayner, C. Reicko, E. Roeckner, K.G. Schnitzler, R. Schnur, K. Strassmann, A.J. Weaver, C. Yoshikawa, N. Zeng, J. Clim. 19, 14, 3337-3343 (2006)

12. M.E. Probert, P.S. Carberry, R.L. McCown, J.E. Turpin, Aust. J. Agric. Res. 49, 317327 (1998)

13. Z. Luo, E. Wang, I.R.P. Fillery, L.M. Macdonald, N.I. Huth, J.Baldock, Agric. Ecosyst. Environ. 186, 94-104 (2014)

14. Y. Apriyana, E. Surmaini, W. Estiningtyas, A. Pramudia, F. Ramadhani, S. Suciantini, E. Susanti, R. Purnamayani, H. Syahbuddin, Sustainability. 13, 11, 6495 (2021) 